BUNCHER CAVITY RESONANT AT THE FIRST AND SECOND HARMONIC

by

Martyn H, Foss
This report was prepared as an eccount of wotk sponsored by the United States Government. Neither the United States nor the United States Deparment of Enetry. nor any of their employees, nor any of their contratcors, subeontractors, or their employees, makes

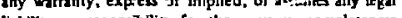
leability or responsibentry for the securacy. completeness or weitulness of any infn-atation, apparalus, product or process disclosed, $6 . \pi$ presents that its use would not infringe privatsiy owned rights. 


\section{BUNCHER CAVITY RESONANT AT THE FIRST AND SECOND BARMONIC*}

Martyn H. Fosg

\section{Abstract}

A bumcher is an RF accelerator followed by a drift space. Its puxpose is to b veh the de lon source bean Into suftable bunches for acceleration in a linac. The voltage in a simple buncher is a sine wave at the linac frequency. A core elaborate wave form can result In increased capture of fon source beam. The caylties discussed here are resonant at 12.5 and $25 \mathrm{MHz}$, the first and second harmonle of the Argonne National Laboratory (ANL) low beta linac. They wlll support a wave form which should glve Improved bunching. Three designs are given to compare their relative merits.

\section{D1scussion}

The cavities shown in Fig. 1 are coaxtal structures. The Inner conductor is zrounded at the top and jopen circult at the bottom. In a complete design, a drift tube for accelerating the beam would be connected to the bottom end by a stub. $\mathrm{Mll}$ are resonant at $\mathbf{1 2 . 5}$ and $25 \mathrm{kHz}$ and vould be suttable for use as a buncher for a $12.5 \mathrm{MHz}$ linac. The cavity on the left is easy to build, the center cavity requires less power, and the cavity on the right is smaller.

These three structures were, decermined by cut and diry using the progran Superfish 1,2 , Big. 1 is Superfish output shoting the outise of the cavity with the eenter line on the left. A fer electric field lines are also shown.

These resonators are tured with Iruped capacity near the shorted end and at the open end. The large cipacity at the drift tube end reduces voltage fluctuations due to beam loading. The charge in an Ideal Iinac bunch is (rf frequency) coulembs per ampere of IInac beam. In the case of the cavity on the left, Fig. 1.1, if the bunch charge were all in the drift tube then the voltage would change by about $300 \mathrm{~V}$ per ampere of beam current. This would be about the same for the cavity on the right, EIg. 1.3, but would $\mathrm{k}$. twice as large for the center cavity due to the smaller caprsity. A $10 \mathrm{w}$ impedance connecticn between the dxift tube and the bottom of the line is necessary to make the charge on the condenser avallable to the beam.

The shunt imfedance of the cavity on the left, Fig. 1.1, Is about $\frac{1}{i} \Omega$. The center cavity has about half the capacity of the one on the left, and thus requires half the charging curtent. It has, however, about torice the Inductance, thus twice the resistance. The center cavity therefore takes about half the power. The one on the right, Fig. 1.3, has capacity and Inductance simllar to that in EIg. 1.1. The resistance is slightly greater so the power is slibitly greater than that of the resonator in Fig.1.1.

\section{Sumary}

Three coaxdal structures which are resonant at 12.5 and $25 \mathrm{Mll} z$ are presented. They could be used as buncher cavities resonant at the first and second harmonic for a $12.5 \mathrm{sHz}$ linac. For simplicity the drift tube, which would be connected to the high voltage end, has been neglected.

In the first example constructinn would be relatively simple. The other two examples shor that reduced power or reduced cavity length can be achleved by using hollow electrodes for capacity loading. Large capacity of the high voltage electrode mininizes bean loading problems in this type of structure.

\section{Aknowledgenent}

I vish to thank $R$. Lari for the figures.

\section{References}

1. D. Haltach and B. F. Holsinger, "Superfish-A Computer Progran for Evaluation of RF Cruities with Cylindrical Symetry." Particle Accelezators, Vo1. 7, pp 213-222, (1976).

2. R. Early, Stanford Superfish, private cousunication.

3. R. LarI, Argonne Superfish Graphics. 


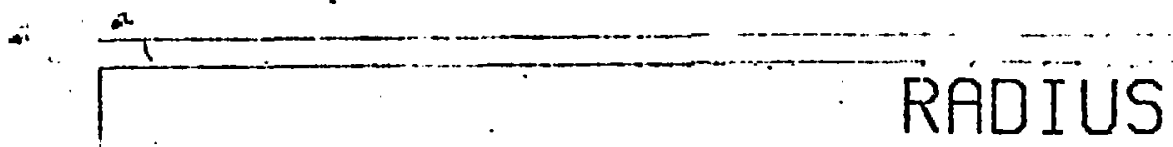

RADIUS

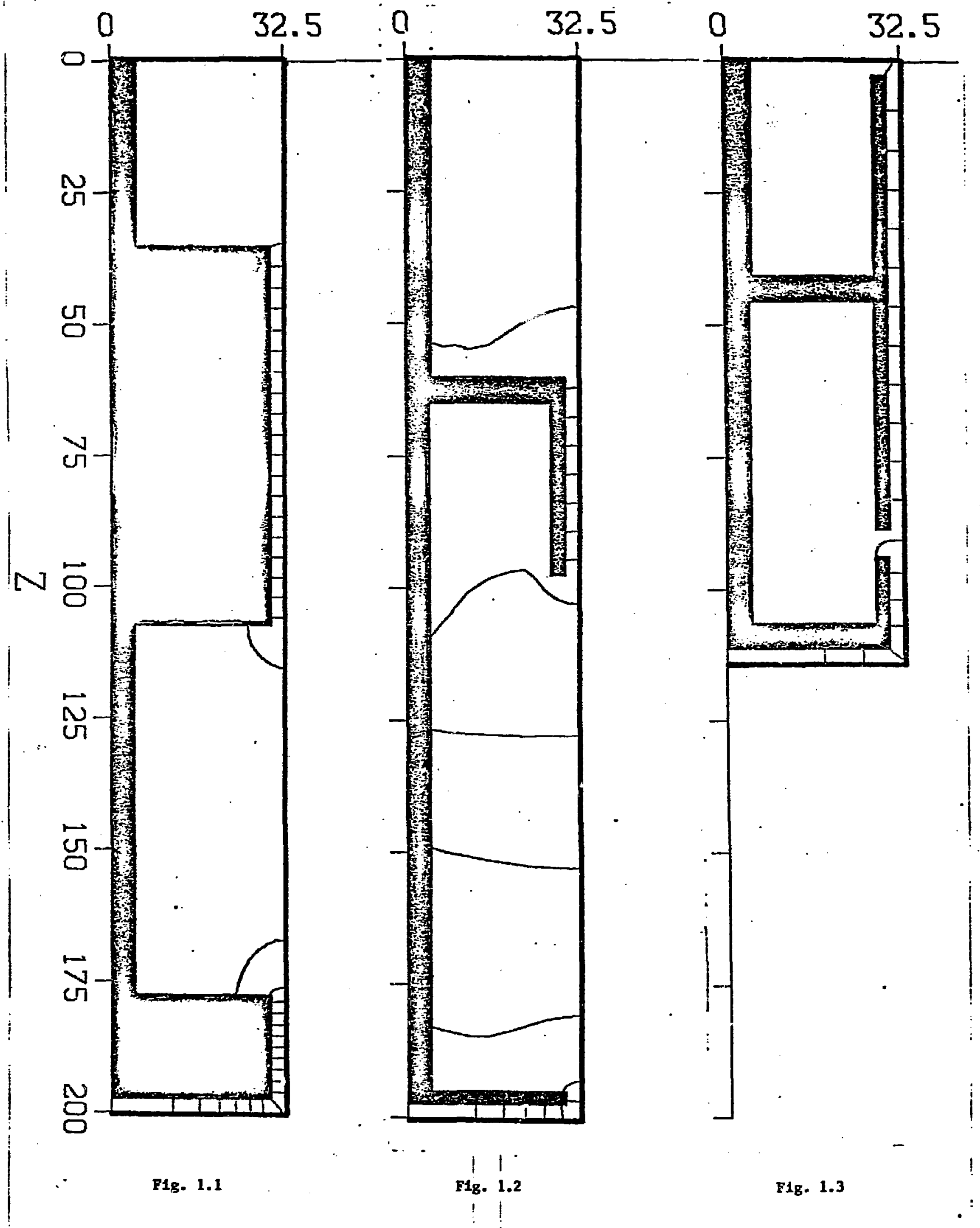

